\title{
EUTANÁSIA SOCIAL, DIREITO À SAÚDE E OS DIREITOS DA PERSONALIDADE: UM OLHAR SOBRE A POBREZA EXTREMA
}

\author{
SOCIAL EUTHANASIA, RIGHT TO HEALTH AND \\ PERSONALITY RIGHTS: A LOOK AT EXTREME POVERTY
}

DIRCEU PEREIRA SIQUEIRA ${ }^{1}$

BRUNA CAROLINE LIMA DE SOUZA ${ }^{2}$

\section{RESUMO}

O direito à saúde se configura entre os direitos mais importantes, na medida em que ele se faz necessário para a preservação da própria vida humana, além de encontrar íntima ligação com o princípio da dignidade da pessoa humana. Todavia, o cenário atual demonstra um grande descaso estatal com relação a efetivação desse direito, que acaba gerando, entre outras consequências, a ocorrência da mistanásia, ou seja, a antecipação da morte de uma forma miserável e sofrida. Deste modo, o artigo terá como problemáticas os questionamentos sobre: qual a importância da efetivação desse direito à todos? Como a mistanásia ainda permanece invisível nos debates jurídicos e sem uma responsabilização ao agente violador? Como esse fenômeno pode vigorar como forma de exclusão social institucionalizada das camadas pobres e extremamente pobres? Assim, tem-se como objetivo geral fazer uma análise crítica da eutanásia social como fruto da ineficiência estatal e como fenômeno institucional de exclusão da camada populacional abarcada pela pobreza extrema, e de modo específico, objetivará fazer uma análise acerca do direito à saúde e da sua relação com a dignidade da pessoa humana e com os direitos da personalidade e da necessidade de sua efetivação por parte do Estado, para posteriormente ser possível analisar a mistanásia de forma crítica, e como tal fenômeno pode se mostrar como fator de exclusão social principalmente das camadas mais pobres da população. Para tanto, se utilizará o método hipotético-dedutivo e a metodologia de revisão bibliográfica.

PALAVRAS CHAVE: Mistanásia. Abandono público. Reserva do possível. Mortes. Pobres.

1 Coordenador e Professor Permanente do Programa de Doutorado e Mestrado em Direito do Centro Universitário Cesumar (UniCesumar); Pós-doutor em Direito pela Faculdade de Direito da Universidade de Coimbra (Portugal), Doutor e Mestre em Direito Constitucional pela Instituição Toledo de Ensino - ITE/Bauru, Especialista Lato Sensu em Direito Civil e Processual Civil pelo Centro Universitário de Rio Preto, Pesquisador Bolsista - Modalidade Produtividade em Pesquisa para Doutor PPD - do Instituto Cesumar de Ciência, Tecnologia e Inovação (ICETI), Professor nos cursos de graduação em direito da Universidade de Araraquara (UNIARA) e do Centro Universitário Unifafibe (UNIFAFIBE), Professor Convidado do Programa de Mestrado University Missouri State - EUA, Editor da Revista Direitos Sociais e Políticas Públicas (Qualis B1), Consultor Jurídico, Parecerista, Advogado. E-mail: dpsiqueira@uol.com.br.

2 Mestranda em Ciências Jurídicas pelo Centro Universitário de Maringá (UNICESUMAR), na condição de Bolsista da CAPES (Modalidade Bolsa/ PROSUP); Bacharel em Direito pela mesma Instituição, na condição de bolsista PROUNI. brunacarolinelimadesouza@gmail.com.

Agência de fomento: Instituto Cesumar de Ciência, Tecnologia e Inovação (ICETI) 


\section{ABSTRACT}

Right to health is one of the most important rights, once it is necessary to preserve human life itself. It also has a close connection with the dignity of the human person. However, the current scenario shows a great state neglect about this right effectuation. It generates, among others consequences, mysthanasia, or in other words, death anticipation in a miserable and suffered way. Thus, this paper will show problems using questions about: What is the effectuation of this right importance to everyone? How is mysthanasia still invisible in legal debates without charge the violator agent? How this phenomenon can hold as a social exclusion form institutionalized from poor people's layers and extremely poor? Therefore, there is, as a main goal, a critical analysis about social euthanasia as a state inefficiency fruit and as an institutional phenomenon of populational layer exclusion connected to extreme poverty. And also, as specific objective, this paper aims to analyze the right to health, its relation with the dignity of the human person and with personality rights, and the necessity of its state effectuation, enabling, then, the analysis of mysthanasia in a critical way and of how this phenomenon can be shown as a social exclusion, mainly of the poorest population layers. Therefore, it used the hypothetical-deductive method and the literature review methodology.

KEYWORDS: Mysthanasia. Public abandonment. Reserve for contingencies. Deaths. Poor people.

\section{INTRODUÇÃO}

No mundo pós-moderno, o princípio da dignidade da pessoa humana possui uma importância ímpar dentro do cenário jurídico nacional e internacional, irradiando seus efeitos para o reconhecimento de inúmeros direitos fundamentais, entre eles o direito à saúde. Tal direito figura não apenas como um direito fundamental (social) mas também como um direito humano, ou seja, um direito que deve ser garantido à toda e qualquer pessoa em toda a extensão mundial.

Tal importância se dá em razão da estreita ligação que o direito à saúde possui com o direito à vida, principalmente à vida digna, podendo inferir sua importância inclusive entre os direitos que tutelam o pleno desenvolvimento da personalidade humana, dada a sua correlação com o núcleo norteador da dignidade da pessoa humana.

Todavia, em função do mesmo se enquadrar entre os direitos fundamentais sociais, ou seja, entre os direitos que dependem da ingerência do Estado para se efetivarem, não raras são as vezes em que o poder público alega ausência de recursos para garantir materialmente o acesso à saúde à todos, fazendo com que um problema cruel advenha: a eutanásia social ou mistanásia, fenômeno esse que antecipa a morte de inúmeras pessoas, de forma miserável, cruel e dolorosa, em razão principalmente do abandono público com relação à efetivação de um direito à saúde que seja, de fato, acessível à todos.

Assim, o presente artigo possui como problemáticas os questionamentos sobre: qual é a importância da efetivação do direito à saúde à todos? Como a mistanásia, que ocorre corriqueiramente no Brasil, permanece quase invisível dentre os debates jurídicos no cenário contemporâneo? E, como tal fenômeno pode vigorar como uma forma de exclusão social institucionalizada das camadas pobres e extremamente pobres?

Tendo em vista as problemáticas que envolvem o artigo, tem-se como hipótese primeira o fato de que o debate jurídico sobre a eutanásia social é infrequente pois o responsável por tal ato é justamente o Estado, que deixa de ser responsabilizado em razão de se 
revestir de proteção, sob o manto da ausência de recursos financeiros e da reserva do possível, proteção essa aceita e chancelada por boa parte dos juristas. Ademais, no que tange a como a mistanásia pode vigorar como uma forma de exclusão social institucionalizada dos pobres, a hipótese vai no sentido de que as pessoas que dependem exclusivamente da rede pública de saúde para tratar de doenças são essencialmente a camada populacional mais pobre que, além de já encontrar-se financeiramente vulnerável, quando doentes, têm também uma vulnerabilidade física externada, de modo que a omissão ou imprudência do Estado com relação a essas vidas, ao ponto de promover-lhes uma morte sofrida, acabam por promover também a exclusão social dessas pessoas, seja antes da morte, ao inviabilizar o acesso à saúde ou a um tratamento qualitativo, seja após, com a morte ocorrida antes ou fora do tempo.

Para tanto, terá como objetivo geral fazer uma análise crítica da eutanásia social como fruto da ineficiência estatal com relação a efetivação do direito à saúde à todos, e como um fenômeno institucional de exclusão dos mais pobres do cenário social, através da promoção (ou no mínimo de uma permissão) estatal de mortes indignas, infelizes e antes ou fora da hora. E objetivará, de modo específico, fazer uma análise acerca do direito à saúde e da sua relação com o direito à vida e a dignidade da pessoa humana, bem como das questões atinentes ao mesmo como um direito humano, fundamental e da personalidade, e da necessidade de sua efetivação por parte do Estado para, então, ser possível analisar a eutanásia social (ou mistanásia) de forma crítica, abordando os principais aspectos característicos da mesma e da sua ocorrência como resultado advindo da não efetivação do direito à saúde à todos, bem como a forma como tal fenômeno pode se mostrar como fator de exclusão social principalmente das camadas mais pobres da população.

Com vistas a realizar a análise do tema, será utilizado o método hipotético-dedutivo, o qual parte de premissas gerais, tais como os direitos fundamentais (direito à vida, à saúde,...) e o princípio da dignidade da pessoa humana, para posteriormente adentrar uma análise específica, qual seja a da eutanásia social e dos aspectos que a permeiam.

Quanto a metodologia adotada, o artigo pautará no método de revisão de literatura, valendo-se de artigos, livros e capítulos de livros, sejam eles físicos, provenientes de revistas eletrônicas nacionais ou contidos em plataformas brasileiras, com o fim de aferir quais os entendimentos acerca dos direitos que envolvem a eutanásia social (vida, saúde, princípio da dignidade humana, etc.), como e porque essa se dá, a atuação estatal na sua ocorrência, como ela vigora como fator de exclusão social, entre outros, bem como de artigos disponíveis em plataformas internacionais, como a Ebsco e a SSRN, visando analisar os debates internacionais acerca dos aspectos que serão delineados no artigo, como direito à saúde, direitos humanos e dignidade humana. 


\section{O DIREITO FUNDAMENTAL, HUMANO \\ E DA PERSONALIDADE À SAÚDE}

\subsection{DIREITO À SAÚDE: DA FUNDAMENTALIDADE À EFETIVAÇÃO DESSE DIREITO}

Inicialmente, antes de adentrar especificamente ao direito à saúde, faz-se necessário destacar a importância que o princípio da dignidade da pessoa humana possui para todo o ordenamento jurídico, na medida em que ele consiste "no ponto nuclear onde se desdobram todos os direitos fundamentais do ser humano" (SZANIAWSKI, 2005, p. 142), inclusive o direito à saúde.

A dignidade da pessoa humana, em sua concepção mais atual, encontra-se ainda muito fundamentada e até mesmo conceituada a partir do pensamento kantiano (SARLET, 2009-a, p. 37), que sustenta que no reino dos fins tudo tem um preço ou uma dignidade (KANT, 1980, p. 140) e que "o Homem, e, duma maneira geral, todo ser racional, existe como um fim em si mesmo, não simplesmente como meio para uso arbitrário desta ou daquela vontade" (KANT, 1980 , p. 134-135). Kant tece, assim, que a qualidade peculiar e insubstituível do ser humano, enquanto ser racional, é ser dotado de uma dignidade, o que se desdobra nessa capacidade de exercício da autonomia da vontade.

A dignidade da pessoa humana se revela, assim, no maior entre os princípios e naquele que deve ser utilizado de parâmetro interpretativo para todos os demais (MORAES, 2019, p. 19), e cuja conceituação é de difícil ou impossível tarefa, por se tratar de um conceito "fluído, multifacetário e multidisciplinar" (SZANIAWSKI, 2005, p. 140), mas se assenta, essencialmente, sobre "o pressuposto de que cada ser humano possui um valor intrínseco e desfruta de uma posição especial no universo" (BARROSO, 2014, p. 14) e cuja função primordial é "atribuir força normativa à Constituição e conferir eficácia máxima aos direitos fundamentais negativos e prestacionais" (WEDY, 2018, p. 206).

Nesta perspectiva é que se tem a utilização da dignidade da pessoa humana ${ }^{3}$ como princípio fundamental matriz, gerador de outros direitos fundamentais (SZANIAWSKI, 2005, p. 143), pois nela se evidencia sempre uma conotação de respeito ao ser humano (MORAES, 2019, p. 21). Nesse sentido, Ingo Wolfgang Sarlet (2009-b, p. 37) ensina que:

Tem-se por dignidade da pessoa humana a qualidade intrínseca e distintiva reconhecida em cada ser humano que o faz merecedor do mesmo respeito e consideração por parte do Estado e da comunidade, implicando, nesse sentido, um complexo de direitos e deveres fundamentais que assegurem a pes-

3 Sobre a tutela da dignidade da pessoa humana no âmbito internacional, Mary Neal defende: "A ideia de dignidade está, obviamente, intimamente associada aos direitos, mas nenhum "direito à dignidade" específico é enumerado no direito internacional ou no direito interno do Reino Unido. Em vez disso, a dignidade parece ser geralmente considerada uma justificativa subjacente aos direitos substantivos ou uma 'fonte de direitos', implicando (i) que a dignidade não é um direito substantivo em si; e (ii) que a dignidade é mais abrangente e mais fundamental do que qualquer um dos direitos individuais que ela fundamenta" - tradução livre. NEAL, 2014, p. 31: "The idea of dignity is, of course, very intimately associated with rights, but no specific 'right to dignity' is enumerated either in international or in UK domestic law. Instead, dignity seems usually to be regarded as an underpinning justification for substantive rights, or a 'source of rights', implying (i) that dignity is not a substantive right in itself, and (ii) that dignity is more overarching, and more fundamental, than any of the individual rights it grounds". 
soa tanto contra todo e qualquer ato degradante e desumano, como venham a lhe garantir as condições existenciais mínimas para uma vida saudável [...].

Ademais, e evidenciando a sua importância dentro do ordenamento jurídico brasileiro, a Constituição Federal de 1988 trouxe a dignidade da pessoa humana em seu art. $1^{\circ}, \mathrm{III}^{4}$, como um dos fundamentos da República Federativa do Brasil, tratando-a como o "epicentro axiológico da ordem constitucional, irradiando efeitos sobre todo o ordenamento jurídico" (SARMENTO, 2004, p. 109).

Assim, o princípio da dignidade da pessoa humana pode ser vislumbrado sob dois aspectos, pois de um lado representa uma qualidade substancial do ser humano e expressão da essência da dignidade humana, e de outro, como fundamento da ordem política e paz nacional, que o faz ser uma fonte de direitos (SZANIAWSKI, 2005, p. 143).

Nesta perspectiva, tem-se que o direito à saúde e todos os demais direitos fundamentais, sejam eles de índole individual, social ou difusa, devem ser sempre analisados sob a óptica da dignidade da pessoa humana, principalmente no que tange à sua matriz geradora de direitos que garantem condições existenciais mínimas para o exercício de uma vida digna, pois, os "direitos sociais, econômicos e culturais, seja na condição de direitos de defesa (negativos), seja na sua dimensão prestacional (atuando como direitos positivos), constituem exigência e concretização da dignidade da pessoa humana" (SARLET, 2009-a, p. 100).

Assim, tem-se que o direito à saúde, dada a sua importância para a concretização da dignidade da pessoa, tem a sua tutela tanto no ordenamento jurídico internacional, estando previsto em documentos como a Declaração Universal dos Direitos Humanos $(1948)^{5}$ e o Pacto Internacional Sobre Direitos Econômicos, Sociais e Culturais (1966) ${ }^{6}$, quanto no nacional, prevista no artigo $6^{\circ}$ da Constituição Federal de $1988^{7}$ e no art. $196^{8}$ a 200 do mesmo diploma, configurando-se, assim, como um legítimo direito humano e fundamental (social).

Todavia, as meras previsões internacionais e constitucionais desse direito não são suficientes para que o mesmo se concretize, é necessário ir além, criando políticas públicas que os efetivem, tarefa essa que incumbe prioritariamente ao Estado, principalmente na vigência de um Estado Democrático Social de Direito, que "apresenta-se como ente garantidor de recursos mínimos para uma vida digna" (OTERO; MASSARUTTI, 2016, p. 856). Nesse sentido, tem-se os ensinamentos de Cleber Sanfelici Otero e Marcelo Luiz Hille (2013, p. 490):

4 Art. $1^{\circ}$ A República Federativa do Brasil, formada pela união indissolúvel dos Estados e Municípios e do Distrito Federal, constitui-se em Estado Democrático de Direito e tem como fundamentos: [...] III - a dignidade da pessoa humana;

5 Declaração Universal dos Direitos Humanos, Artigo XXV: 1- Todo ser humano tem direito a um padrão de vida capaz de assegurar-Ihe, e a sua família, saúde e bem-estar, inclusive alimentação, vestuário, habitação, cuidados médicos e os serviços sociais indispensáveis, e direito à segurança em caso de desemprego, doença, invalidez, viuvez, velhice ou outros casos de perda dos meios de subsistência em circunstâncias fora de seu controle.[...] - grifo inexistente no original.

6 Pacto Internacional Sobre Direitos Econômicos, Sociais e Culturais, Artigo 12: 1. Os Estados Partes do presente Pacto reconhecem o direito de toda pessoa de desfrutar o mais elevado nível possível de saúde física e mental. 2. As medidas que os Estados Partes do presente Pacto deverão adotar com o fim de assegurar o pleno exercício desse direito incluirão as medidas que se façam necessárias para assegurar: a) A diminuição da mortinatalidade e da mortalidade infantil, bem como o desenvolvimento é das crianças; b) A melhoria de todos os aspectos de higiene do trabalho e do meio ambiente; c) A prevenção e o tratamento das doenças epidêmicas, endêmicas, profissionais e outras, bem como a luta contra essas doenças; d) A criação de condições que assegurem a todos assistência médica e serviços médicos em caso de enfermidade.

7 Art. $6^{\circ}, \mathrm{CF} / 1988$ : São direitos sociais a educação, a saúde, a alimentação, o trabalho, a moradia, o transporte, o lazer, a segurança, a previdência social, a proteção à maternidade e à infância, a assistência aos desamparados, na forma desta Constituição.

8 Art. 196. A saúde é direito de todos e dever do Estado, garantido mediante políticas sociais e econômicas que visem à redução do risco de doença e de outros agravos e ao acesso universal e igualitário às ações e serviços para sua promoção, proteção e recuperação. 
Ao ser defendido o princípio da dignidade, busca-se o respeito à vida, à integridade física e à integridade moral do ser humano.

Cabe, assim, ao Estado Democrático de Direito prover meios para que sejam asseguradas as garantias mínimas para a existência digna de todo ser humano, mediante o reconhecimento e a proteção dos direitos fundamentais, tais como a liberdade, a igualdade, o acesso à saúde e à educação, entre outros.

Assim, para a concretude do princípio da dignidade da pessoa humana devem haver garantias mínimas, que é a própria essência dos direitos fundamentais, os quais vinculam "o poder público como um todo, bem como os particulares, pessoas naturais ou jurídicas" (SZANIAWSKI, 2005, p. 142). Assim, Cleide Aparecida Gomes Rodrigues Fermentão (2007, p. 73) ensina que configuram-se "agressões à dignidade humana, a ausência de moradia, habitação, educação, saúde [...]", impondo principalmente ao poder público a efetivação dos mesmos.

Nesse mesmo sentido ensina Luis Roberto Barroso (2003, p. 38):

O conteúdo jurídico do princípio vem associado aos direitos fundamentais, envolvendo aspectos dos direitos individuais, políticos e sociais. Seu núcleo material elementar é composto do mínimo existencial, locução que identifica o conjunto de bens e utilidades básicas para subsistência física e indispensável ao desfrute da própria liberdade. Aquém daquele patamar, ainda quando haja sobrevivência, não há dignidade. 0 elenco de prestações que compõe o mínimo existencial comporta variação conforme a visão subjetiva de quem o elabore, mas parece haver razoável consenso de que inclui: renda mínima, saúde básica e educação fundamental.

Conforme se observa, o direito à saúde sempre vem especificado entre os principais direitos que constituem o mínimo existencial que deve ser garantido à todos, o que se dá justamente pela íntima ligação que possui com o direito à vida e principalmente com o direito à vida digna9.

Todavia, a questão da efetivação de direitos fundamentais sociais como o direito à saúde envolve necessariamente a imprescindibilidade de que haja prestações positivas do Estado (VIDAL DE SOUZA; SANOMIYA, 2017, p. 394), visto que configura-se como "um direito público subjetivo, exigível contra o Estado, posto que seu exercício e efetividade dependem de aporte de recursos materiais e humanos a serem implementados por meio de políticas públicas de saúde" (BAHIA; ABUJAMRA, 2009, p. 303), o que implica, consequentemente, no debate acerca das limitações do orçamento do Poder Público.

Todavia, tal debate "é agravado no cenário brasileiro em virtude da crise econômica, política e social que se evidencia atualmente no Brasil" (SELAYARAN; MACHADO; MORAIS, 2018, p. 10), havendo, assim, o acolhimento por parte da doutrina e jurisprudência da aplicação da denominada "reserva do possível", que consiste num "conceito originário - e ontologicamente despretensioso -, na limitação argumentativo-fática à implementação dos direitos sociais em razão de insuficiência orçamentária para tal" (BERNARDI; LAZARI In SIQUEIRA;

9 Nesse sentido: "O mínimo existencial trabalha com a efetivação de direitos fundamentais considerados mínimos para o alcance de uma vida digna, vincula a atividade estatal na execução de políticas públicas para a materialização do direito à saúde, segurança, moradia, educação, entre outros" - tradução livre. MACIEL-LIMA; OLIVEIRA; DOMINGOS, 2018, p. 239: "The existential minimum works with the effectuation of fundamental rights considered as minimum for the reach of a dignified life, links state activity in the execution of public policies for the materialization of the right to health, safety, housing, education, among others". 
LEÃO JUNIOR, 2011, p. 254), utilizada pelo poder público como forma de "se eximirem das responsabilidades prestacionais na área da saúde, como também em outras, dentro do contexto de direitos sociais" (TASCA, 2013, p. 100).

Ocorre que, sem negar a existência de limitações estatais de cunho financeiro para a efetivação de todos os direitos sociais, tal argumento não pode ser utilizado pelo Estado para não oferecer prestações e serviços quando está em questão o mínimo necessário para as pessoas viverem e sobreviverem com respeito e dignidade (OTERO; HILLE, 2013, p. 501), o que é o caso do direito à saúde, pois "mesmo que o recurso orçamentário seja pequeno, é fundamental assegurar provisão orçamentária para esse mínimo considerado essencial" (BERTOLAIA; PALAZZOLO, 2016, p. 296) . Nesse sentido, Sarlet e Figueiredo (2007, p. 201) delineiam que:

[...] em matéria de tutela do mínimo existencial (o que no campo da saúde, pela sua conexão com os bens mais significativos para a pessoa) há que se reconhecer um direito subjetivo definitivo a prestações e uma cogente tutela defensiva, de tal sorte que, em regra, razões vinculadas à reserva do possível não devem prevalecer como argumento a, por si só, afastar a satisfação do direito e exigência do cumprimento dos deveres, tanto conexos quanto autônomos, já que nem o princípio da reserva parlamentar em matéria orçamentária nem o da separação dos poderes assumem feição absolutas.

Ademais, a reserva do possível só poderá figurar como argumento válido quando estiver efetivamente demonstrado pelos poderes públicos que eventual restrição a direitos sociais foi resultante de um exercício de ponderação entre princípios conflitantes, no qual se cumpriu os requisitos da proporcionalidade e com a preservação do conteúdo mínimo necessário para a garantia de uma vida digna (KELBERT, 2011, p. 106) ou "para aquelas situações que extrapolem o mínimo existencial e que se refiram aos indivíduos que possuam meios de obter por si só a prestação pretendida" (RIBEIRO, 201 1, p. 89). Acrescenta-se ainda os ensinamentos de Otero e Massarutti (2016, p. 856-857), de que:

[...] a vida digna possui um núcleo dentro do princípio da dignidade humana, que é o mínimo de condições ou instrumentos assecuratórios para uma existência com dignidade, o qual não pode ser afetado em nenhuma hipótese. Se o administrador público ou o legislador tiver que fazer uma escolha entre direitos fundamentais a serem concretizados, ele até poderá realizar esta opção com supedâneo na cláusula da reserva do possível, mas jamais estará autorizado a atingir o mínimo capaz de proporcionar uma existência digna.

Nesse sentido, pelo menos do ponto de vista teórico, a saúde, como parte integrante de um mínimo de recursos necessários para uma existência digna não poderia sofrer qualquer tipo de restrição [...]

Assim, é imperativa a necessidade de atuação estatal no sentido de investimento em políticas públicas de saúde que satisfaçam a necessidade de todos, não apenas no que se refere ao âmbito de reparação, mas também de prevenção e promoção da mesma, nos termos do art. 196 da Constituição Federal Brasileira de 1988, bem como coadunando com a definição de saúde da OMS (Organização Mundial da Saúde), que a define como "um estado de completo bem-estar físico, mental e social, e não consiste apenas na ausência de doença 
ou de enfermidade"10, ou seja, "o conceito de saúde engloba o equilíbrio biopsicossocial da pessoa humana" (SIQUEIRA; LAZARETTI, 2019, p. 310) e não pode ser visto apenas como a ausência ou cura de doenças, mas sim em uma perspectiva mais ampliada de prevenção de enfermidades e promoção da qualidade de vida (MASSAFRA, 2004, p. 66), não podendo arguir o Estado - em razão da sua inércia, ineficácia ou ineficiência na efetivação do direito à saúde (em seu conceito amplo) e na aplicação correta do dinheiro público - a justificativa da reserva do possível como mecanismo legitimador da não-garantia material desse direito essencial para preservação da própria vida (digna) humana.

\subsection{DIREITO À SAÚDE: UM LEGÍTIMO DIREITO DA PERSONALIDADE}

Conforme destacado anteriormente, o direito à saúde tem uma íntima relação com o direito à vida e com a dignidade da pessoa humana, configurando-se como necessário para a garantia do mínimo existencial do ser humano e, com previsão no ordenamento jurídico tanto como um direito humano como um direito fundamental. Todavia, é possível também o seu enquadramento enquanto um direito da personalidade, ou seja, o pertencimento ao rol de direitos tão "essenciais ao desenvolvimento e realização da pessoa, que fundados na dignidade da pessoa humana, garantem o gozo e respeito ao seu próprio ser, em todas as dimensões, espirituais e físicas" (FOLLONE; RODRIGUES In SIQUEIRA; AMARAL, 2017, p. 317).

No que se refere aos direitos da personalidade, a nossa Constituição não inseriu um dispositivo específico que os tutela, porém acaba por reconhecer e tutelar o direito geral de personalidade por meio do princípio da dignidade humana, que vigora como uma cláusula geral de concreção da proteção e desenvolvimento da personalidade do indivíduo, visto que tal princípio, figurando como um princípio fundamental diretor que deve servir de interpretação para todo o ordenamento jurídico, acaba por se constituir na cláusula geral de proteção da personalidade, na medida em que a pessoa natural é o primeiro e o último destinatário da ordem jurídica (SZANIAWSKI, 2005, p. 137).

Os direitos da personalidade são tão importantes que Adriano de Cupis defende que sem eles "a personalidade restaria uma susceptibilidade completamente irrealizada, privada de todo o valor completo: direitos sem os quais todos os outros direitos subjetivos perderiam todo o interesse para o indivíduo - o que equivale a dizer que, se eles não existissem, a pessoa não existiria como tal" (CUPIS, 2004, p. 24).

Assim, tem-se que os direitos da personalidade possuem por fundamento o princípio da dignidade da pessoa humana, que é o que permite defender a tutela de um direito geral da personalidade, e são direitos que possuem ligação precípua com a própria possibilidade de pleno desenvolvimento da pessoa e de sua personalidade, garantindo, assim, o próprio exercício do "ser", em todas as suas diversas dimensões.

Deste modo, a proteção ao pleno desenvolvimento da personalidade de cada pessoa não deve levar em conta tão somente direitos individuais, como vida e liberdade, e deixar de lado a tutela de direitos essenciais para o próprio asseguramento daqueles, direitos sem

10 Definição contida no preâmbulo da Constituição da Organização Mundial da Saúde. Disponível em: http://www.direitoshumanos.usp.br/index.php/OMS-Organiza\%C3\%A7\%C3\%A3o-Mundial-da-Sa\%C3\%BAde/constituicao-da-organizacao-mundial-da-saude-omswho.html. Acesso em: 20 nov. 2019. 
os quais não se pode sequer falar em vida e principalmente em vida digna, como o direito à saúde ou à alimentação. São direitos que, uma vez ausentes, impossibilitam ou, no mínimo, prejudicam o pleno desenvolvimento da pessoa e de sua personalidade. Nesse sentido, importante os ensinamentos de Rabindranath Capelo de Souza (1995, p. 516), de que:

[...] a personalidade <física > ou <moral> referida no art. $70 .^{\circ}$ do Código Civil abrange quer os bens ligados à realidade física de cada homem (homo phoenomenon) quer os bens inerentes à sua autonomia e liberdade (homo noumenon), que com essa disposição legal se protege não apenas o essencial da personalidade de todos os homens (humanitas) mas também a particular individualidade e irrepetibilidade de cada um (individualitas) e que a tutela da personalidade humana exige não apenas a proteç̧ão dos seus bens interiores mas também o resguardo e a preservação do espaço vital exterior de cada homem. (destaque nosso)

Desta feita, o direito à saúde, principalmente ao reservar uma íntima ligação com o direito à vida, acaba por ser "um direito fundamental que guarda relação com o pleno desenvolvimento da personalidade humana e integra o direito ao mínimo para uma vida digna [...]" (OTERO; MASSARUTTI, 2016, p. 849), podendo ser incluído também não apenas como um direito humano e fundamental, mas também como um direito da personalidade, ressaltando a importância da sua tutela e efetivação.

Ademais, tal afirmativa pode ser inclusive fundamentada nos ensinamentos de Fernanda Cantali (2009, p. 217), que defende que a busca pela efetividade do princípio da dignidade da pessoa humana - que é a cláusula geral de proteção da personalidade humana - impõe uma atuação bifrontal, atuando em uma perspectiva protetiva e promocional, ou seja, garantindo uma esfera de autodeterminação pessoal, expressão da autonomia privada e a liberdade pessoal, mas também garantindo o imperativo de assistência através da ação estatal ou coletiva. Perez Luno (p. 318) também ensina nesse sentido, afirmando que "a dignidade da pessoa humana não constitui apenas uma garantia negativa de que a pessoa não será objeto de ofensas ou humilhações, mas implica também, em sentido positivo, no pleno desenvolvimento da personalidade de cada indivíduo".

Nesta perspectiva, defende Fermentão (2007, p. 75-76):

O Estado Moderno tem como tarefa realizar a tutela dos direitos fundamentais e favorecer o pleno desenvolvimento da pessoa. Assume a obrigação de respeitar os direitos individuais da pessoa, tais como o direito à vida, à liberdade, à informação, ao trabalho, ao estudo, e outros, ambos essenciais e característicos de toda pessoa humana, que tem direitos como cidadão, e, portanto, o Estado tem também o dever de promover tais direitos, eliminando qualquer dificuldade, quer econômicas ou sociais, que possam impedir o efetivo exercício dos direitos pessoais e da cidadania.

0 Estado tem a obrigação de intervir e possibilitar que os interesses existenciais e individuais da pessoa humana sejam exercidos.

Neste diapasão, o princípio da dignidade humana não importa apenas em um limite para os Poderes Públicos, no sentido de abster-se de atentar contra ele, mas sim, traduz um norte para a conduta estatal, impondo uma atitude comissiva das autoridades públicas para a proteção do livre desenvolvimento da personalidade humana, com o asseguramento das condições mínimas para a vida com dignidade (SARMENTO, 2004, p. 113), condições essas 
que incluem um acesso efetivo ao direito à saúde, em nível repressivo, protetivo e promocional.

No Brasil, a Constituição Federal de 1988 trouxe em seu art. 198, que " as ações e serviços públicos de saúde integram uma rede hierarquizada e constituem um sistema único", norma essa que deu origem ao Sistema Único de Saúde (SUS), trazendo no art. $200^{11}$ do mesmo diploma quais são as atribuições desse sistema, que abordam questões atinentes não só à ações que visem o acesso à saúde, mas também de saneamento básico, alimentação, proteção do meio ambiente, entre outros. Posteriormente houve a regulamentação desse sistema pela Lei n 8.080/1990, que prevê, dentre outras coisas, que os serviços públicos de saúde e os serviços privados integrados ao Sistema Único de Saúde devem seguir alguns princípios, entre eles o da universalidade de acesso aos serviços de saúde em todos os níveis de assistência (art. $7^{\circ}$, I, Lei $n^{\circ} 8.080 / 1990$ ), o qual garante a todas as pessoas o acesso às ações e serviços de saúde disponíveis (BARROSO, 2009, p. 41).

Todavia, em que pese a Constituição preveja um direito fundamental de acesso à saúde, o Estado acaba por falhar e não oferece um sistema universal (MACIEL-LIMA; OLIVEIRA; DOMINGOS, 2018, p. 238) ${ }^{12}$, pois a realidade pátria contemporânea tem evidenciado que "o sistema público de saúde tem se mostrado seletivo em face da carência de infraestrutura, que é precária, e de recursos à saúde, que são escassos" (SIQUEIRA; LAZARETTI, 2019, p. 312), visto que o direito à saúde é um direito que, necessariamente, "depende da vontade política, ou seja, da vontade dos Poderes de realizarem políticas, ações e serviços voltados a acabar com a problemática da sua inefetividade" (PICCIRILLO; ZAIA, 2016, p. 323), e que, se ausente tal vontade, a sua eficácia é obstaculizada, podendo, por vezes, evidenciar a existência da eutanásia social ou mistanásia, que se refere a uma morte "lenta, cruel e miserável decorrente do abandono em que se encontra grande parte da população brasileira" (ZAGANELLI; SOUZA; CABRAL; SANCHES, 2016, p. 7), a qual será abordada de modo específico no próximo tópico.

\section{A EUTANÁSIA SOCIAL: O ESTADO COMO AGENTE VIOLADOR DA DIGNIDADE DA PESSOA HUMANA?}

O termo "eutanásia", assim considerada, é uma palavra que vem do grego, derivada de "eu" (boa) e "thanatos" (morte), que em sua origem é entendida como boa morte, morte apropriada, morte piedosa, morte benéfica (SA; NAVES, 2011, p. 95). Assim, acaba sendo compreendida como uma morte digna, indolor.

11 Art. 200. Ao sistema único de saúde compete, além de outras atribuições, nos termos da lei: I - controlar e fiscalizar procedimentos, produtos e substâncias de interesse para a saúde e participar da produção de medicamentos, equipamentos, imunobiológicos, hemoderivados e outros insumos; II - executar as ações de vigilância sanitária e epidemiológica, bem como as de saúde do trabalhador; III - ordenar a formação de recursos humanos na área de saúde; IV - participar da formulação da política e da execução das ações de saneamento básico; $V$ - incrementar, em sua área de atuação, o desenvolvimento científico e tecnológico e a inovação; VI - fiscalizar e inspecionar alimentos, compreendido o controle de seu teor nutricional, bem como bebidas e águas para consumo humano; VII - participar do controle e fiscalização da produção, transporte, guarda e utilização de substâncias e produtos psicoativos, tóxicos e radioativos; VIII - colaborar na proteção do meio ambiente, nele compreendido o do trabalho.

12 No original: "The Constitution provides for a fundamental right of access to health, however, the State fails and not offer a universal system [...]". 
Para se configurar a eutanásia, é necessário compreender se estão presentes 3 (três) requisitos essenciais, quais sejam: a) uma situação de enfermidade terminal incurável ou de invalidez irreversível; b) o motivo humanitário e piedoso do agente; c) a existência de consentimento validamente prestado pelo paciente, se consciente, porém se inconsciente, prevalece o princípio da beneficência, que determina a atuação de terceiros no melhor interesse do paciente (SIQUEIRA; LAZARETTI, 2019, p. 313-315). Ou seja, nela se evidencia que a morte é antecipada para se evitar o sofrimento do paciente que, em razão de algo incurável ou irreversível, não teria uma vida digna se postergada tal situação, de modo que a morte é antecipada de forma indolor para que se tenha uma "boa morte".

Todavia, o que se conhece por eutanásia social ou mistanásia, em nada se assemeIha a eutanásia em si. A expressão mistanásia também tem etimologia grega, derivando de "mis" (infeliz) e "thanatos" (morte), ou seja, traduz a ideia de uma morte sofrida, antes e fora da hora, provocada de forma lenta, sendo uma morte que tem como escopo as desigualdades sociais e provocada, na maioria das vezes, pelo descaso do poder público em relação a classe pobre da sociedade (ZAGANELLI; SOUZA; CABRAL; SANCHES, 2016, p. 7). Assim, importante os ensinamentos de que:

A eutanásia, pelo menos em sua intenção, quer ser uma morte boa, suave, indolor, enquanto a situação chamada eutanásia social nada tem de boa, suave ou indolor. Dentro da grande categoria de mistanásia quero focalizar três situações: primeiro, a grande massa de doentes e deficientes que, por motivos políticos, sociais e econômicos, não chegam a ser pacientes, pois não conseguem ingressar efetivamente no sistema de atendimento médico; segundo, os doentes que conseguem ser pacientes para, em seguida, se tornar vítimas de erro médico e, terceiro, os pacientes que acabam sendo vítimas de má-prática por motivos econômicos, científicos ou sociopolíticos. A mistanásia é uma categoria que nos permite levar a sério o fenômeno da maldade humana. (MARTIN In FERREIRA; OSELKA; GARRAFA, 1998, p. 172)

Deste modo, tem-se que a eutanásia social ou mistanásia se refere às mortes ocorridas em razão de falta de assistência do Estado, por erro médico e por má prática (SIQUEIRA; LAZARETTI, 2019, p. 317). Assim, haverá a ocorrência da mistanásia em três hipóteses: quando os cidadãos sequer chegam a ser pacientes, porque não conseguem ingressar no sistema de saúde em razão de fatores geográficos, políticos e sociais, caracterizando uma omissão de socorro por parte do Estado; quando os cidadãos conseguem o acesso a uma unidade pública de saúde, mas tendo em vista o número grande de pacientes somados à falta de estrutura adequada, acabam não sendo atendidos, persistindo as doenças ou pior, havendo a morte dos mesmos nas filas do Sistema Único de Saúde, ou, quando atendidos, há leitos ou aparelhos insuficientes, obrigando os profissionais da saúde a escolherem quais pacientes atender; ou, ainda, sendo atendidos, acabam sendo vítimas de erro médico (imprudência e negligência) e vindo à óbito (CABETTE, 2009).

Tem-se, assim, que um dos grandes contrapontos entre a mistanásia e a eutanásia é o resultado, pois enquanto aquela acarreta a morte antes da hora, de forma miserável e dolorosa, esta provoca uma morte também antes da hora, porém de maneira suave e sem dor, e é justamente este resultado que torna a eutanásia atraente para muitos e a mistanásia invisível para outros, ou seja, vive-se em uma sociedade que ao mesmo tempo que oferece a mais alta tecnologia para o "bem morrer", nega o indispensável para o "bem viver" (PAOLO; RIBAS; PEREIRA, 2006, p. 274-275). 
Nos dizeres de Dworkin (2003, p. 280),

[...] A morte domina porque não é apenas o começo do nada, mas o fim de tudo, e o modo como pensamos e falamos sobre a morte - a ênfase que colocamos no "morrer com dignidade" - mostra como é importante que a vida termine apropriadamente, que a morte seja um reflexo do modo como desejamos ter vivido.

Assim, a morte, que coloca fim ao sopro da vida, não pode ser simplesmente antecipada pela mera justificativa de que falta recursos ao Estado para investir em infraestrutura, materiais, funcionários da saúde, leitos e remédios, instrumentos esses necessários para dar plena efetividade ao direito à saúde. Aceitar tal justificativa como válida, é o mesmo que aceitar a ocorrência de homicídios em massa, perpetrados sobre aqueles que só possuem o Sistema Único de Saúde como esperança para ter o acesso a uma saúde e vida digna.

Vale a pena ressaltar que o direito à saúde deve ser entendido, ainda, como um "direito de justiça social essencialmente como forma de garantia a uma vida digna" (SILVA; VITA, 2014 , p. 261), de modo que pode-se considerar haver uma hipocrisia cruel e perigosa na preocupação com a oferta de uma "morte digna" quando pouco se age para propiciar aos viventes o respeito pela dignidade humana deles (CABETTE, 2009, p. 31).

Ademais, acerca da mistanásia, acrescenta-se que

Na América Latina, de modo geral, a forma mais comum de mistanásia é a omissão de socorro estrutural que atinge milhões de doentes durante sua vida inteira e não apenas nas fases avançadas e terminais de suas enfermidades. A ausência ou a precariedade de serviços de atendimento médico, em muitos lugares, garante que pessoas com deficiências físicas ou mentais ou com doenças que poderiam ser tratadas morram antes da hora, padecendo enquanto vivem dores e sofrimentos em princípio evitáveis. (MARTIN In FERREIRA; OSELKA; GARRAFA, 1998, p. 175)

Deste modo, a realidade que se revela é que, enquanto se fala na possibilidade de uma mudança legislativa no Brasil para aceitar a ocorrência da eutanásia - que ainda é proibida no Estado Brasileiro ${ }^{13}$ - e voltam-se os holofotes para o debate sobre propiciar uma morte digna àqueles que já não possuem a viabilidade de uma vida futura digna, a discussão acerca da mistanásia, ou seja, das inúmeras mortes miseráveis perpetradas no país em razão unicamente da ausência de uma prestação estatal eficaz e universal do direito à saúde, continuam invisíveis, inexistentes ou abafadas.

E tal cenário se justifica porque a eutanásia social está diretamente relacionada às políticas públicas de saúde e a qualidade de vida que devem fazer parte do planejamento estatal em busca de justiça social (ZAGANELLI; SOUZA; CABRAL; SANCHES, 2016, p. 8) e da própria concretização da dignidade da pessoa humana à todos. Assim, ela se consubstancia justamente em razão da ineficácia e inércia do Estado com relação a promoção de políticas públicas nesse sentido ${ }^{14}$, que acaba atuando justamente em contrário ao seu papel: ao invés

13 Nesse sentido: "[...]as legislações penais brasileiras nunca se interessaram em dispor sobre a eutanásia como um crime propriamente dito. Na doutrina majoritária existe uma tendência no que diz respeito a equiparar a conduta ao homicídio, tipificado no artigo 121 do Código Penal Brasileiro de 1940, vigente na atualidade". (FERREIRA; PORTO, 2017, p. 156).

14 Acerca do papel do estado na promoção do direito à saúde, destaca-se os ensinamentos de Silva e Vita (2014, p. 249): "A garantia do direito social à saúde exige do Estado uma administração passível de implantação de políticas públicas capazes de suprir as necessidades mais urgentes. Dentre elas, destacam-se as necessidades voltadas ao fornecimento de medicamentos gratuitos, contratação e remuneração digna aos profissionais da área da saúde, construção e estruturação de hospitais e postos de saúde públicos, dentre outras necessidades". 
de proteger e promover um acesso à saúde de qualidade à todos, atua como violador da vida, da dignidade humana e até mesmo da morte no tempo certo, e sequer é punido ou responsabilizado por tais violações, mesmo havendo, na teoria, a possibilidade de responsabilização Estatal (apenas na seara civil - não na penal) quando ocorra a prestação insatisfatória do serviço à saúde ${ }^{15}$.

\section{EUTANÁSIA SOCIAL E EXTREMA POBREZA: UMA RELAÇÁO DE EXCLUSÃO SOCIAL}

A pobreza e a extrema pobreza são uma realidade latente principalmente em países subdesenvolvidos como o Brasil, sendo que a visão sobre as mesmas sofreram alteração a partir do século XX, pois o que antes cingia-se tão somente ao poder econômico da pessoa, passa a ser atrelada ainda à situação econômica, porém ampliada, adicionando-se o fato de que a condição primeira da pobreza se dá em razão do impedimento de ter acesso a outros fatores que inibiriam a perpetuação da mesma (FERNANDES, 2017, p. 308) e não se refere somente a carência de bens materiais (TEIXEIRA, 2014, p. 216).

Nesse sentido, importante explicitar acerca da concepção de Amartya Sen, que identifica a pobreza como privação de capacidades:

[...] a pobreza pode sensatamente ser identificada em termos de privação das capacidades, com a abordagem concentrando-se em privações intrinsecamente importantes, em contrapartida com a renda baixa, cujo valor é apenas de forma instrumental; b) existem outras influências sobre a privação de capacidades, portanto sobre a pobreza real, além do baixo nível de renda, já que esta não é o único instrumento de geração de capacidades; c) a relação instrumental entre baixa renda e baixa capacidade é variável entre comunidades e até mesmo entre famílias e indivíduos, aduzindo que o impacto da renda sobre as capacidades é contingente e condicional. (SEN, 2010, p. 121)

Desta forma, a pobreza pode ser compreendida como uma forma de exclusão social, fruto da distribuição desigual de bens essenciais para uma vida digna, bens esses que correspondem à capacidade de indivíduos, famílias e comunidades de suprir suas necessidades básicas (FERNANDES, 2017, p. 309) e configura-se como um fator social que vai muito além do critério reducionista da renda, mencionando Paugam acerca da "desqualificação social", ou seja, da relação que há entre uma população designada como pobre em razão de sua dependência aos serviços sociais e o restante da sociedade (PAUGAN In VERAS, 1999, p. 63-64), colocando-a, assim, como um fenômeno multidimensional (CABRAL JUNIOR; COSTA, 2017, p. 796).

Coadunando com tal pensamento, José Loureiro defende que "a pobreza pode traduzir-se numa privação ou numa insuficiência no acesso à bens fundamentais (v.g., alimenta-

15 Nesse sentido: "Inobstante, ocorrendo a prestação ano satisfatória do serviço de saúde publica, da qual derive um dano, exsurge a responsabilidade estatal. De tal responsabilidade advém o dever de ressarcir o cidadão lesado em virtude da ausência ou da falha no serviço de saúde, através reparação do dano ou de seu ressarcimento, mediante quantum indenizatório, conforme o entendimento da doutrina e da jurisprudência mais atual de nosso país".(GOMES, 2010, p. 183) 
ção, saúde) que põem em causa a própria sobrevivência" (LOUREIRO In CORREA; MACHADO; LOUREIRO, 2012, p. 409).

Assim, é possível extrair das concepções mais modernas acerca da pobreza um denominador comum, qual seja, o de que a pobreza não está apenas atrelada ao fator de baixa renda, mas também encontra-se aliado a questões como a dependência de serviços públicos para obter o acesso a bens fundamentais, como o direito à saúde, à alimentação, à educação, entre outros, acesso esse que, se obtido de modo qualitativo, estaria não só permitindo a vivência digna dessa grande parcela da população, mas também a própria possibilidade de ascensão social e superação da pobreza.

Desta forma, o que se visualiza no que tange as discussões até então tecidas, é que a mistanásia, enquanto uma antecipação da morte de forma miserável e dolorida, - ocasionada principalmente em razão da omissão e abandono público do Estado quanto à efetivação universal do direito à saúde - tem afetado mais justamente as camadas mais pobres da população, uma vez que nelas existem uma dependência direta e exclusiva do Sistema Único de Saúde, sem qualquer possibilidade de recorrer a outro meio para a obtenção de tratamentos médicos, além do fato de que a saúde é um elemento que possui total relação não só com o indivíduo, mas com todo o ambiente social que o rodeia (RAMOS; DINIZ, 2017, p. 174), o que não favorece as populações que vivem em condições de extrema pobreza e que, em sua maioria, sequer possuem um habitat saudável à vida.

Nesse sentido, importante os ensinamentos de Martin (In FERREIRA; OSELKA; GARRAFA, 1998, p. 175):

É precisamente a complexidade das causas desta situação que gera na sociedade um certo sentimento de impotência propício à propagação da mentalidade "salve-se quem puder". Planos de saúde particulares para quem tem condições de pagar e o apelo às medicinas alternativas tradicionais e novas por parte do rico e do pobre, igualmente, são dados sintomáticos de um mal-estar na sociedade diante da ausência de serviços de saúde em muitos lugares e do sucateamento dos serviços públicos e da elitização dos serviços particulares em outros. Numa sociedade onde recursos financeiros consideráveis não conseguem garantir qualidade no atendimento, a grande e mais urgente questão ética que se levanta diante do doente pobre na fase avançada de sua enfermidade não é a eutanásia, nem a distanásia, destinos reservados para doentes que conseguem quebrar as barreiras de exclusão e tornar-se pacientes, mas, sim, a mistanásia, destino reservado para os jogados nos quartos escuros e apertados das favelas ou nos espaços mais arejados, embora não necessariamente menos poluídos, embaixo das pontes das nossas grandes cidades.

Ademais, verifica-se ainda o descaso estatal com relação às "doenças da pobreza", que são assim denominadas porque, mesmo extintas no passado, acabam retornando à realidade vigente em razão de que a população pobre e extremamente pobre acaba não possuindo meios de evitar a contaminação ${ }^{16}$ ou não sabem como fazê-lo e, principalmente,

16 Nesse sentido: "As desvantagens e vulnerabilidades urbanas levam a várias formas de desigualdades na saúde. A ausência de instalações básicas em assentamentos de baixa renda nas áreas urbanas, juntamente com ambientes insalubres e superlotação, cria um ciclo vicioso de infecções, desnutrição e problemas de saúde." - Tradução livre. (SHAFIQUE; BHATTACHARYYA; ANWAR; ADAMS, 2018, p. 63-64). No original: "Urban disadvantage and vulnerability lead to various forms of health inequalities. The absence of basic amenities in low-income settlements in urban areas, together with unsanitary environments and overcrowding, creates a vicious cycle of infections, malnutrition, and poor health". 
quando adoecem, são mal assistidas" (SOUZA, 2011, p. 313-314). Nesse sentido, esclarece Silva e Gonçalves (2013, p. 565):

Basta ver, por exemplo, o descaso institucional com as chamadas doenças da pobreza. É admirável, na acepção depreciativa da palavra, a resignação do governo em relação à existência de doenças consideradas superadas, mas que acometem e levam a óbito considerável parcela da população pobre, miserável e os residentes de regiões longínquas do Brasil. Fato comprovado pelo alto número de novos casos de tuberculose e leishmaniose no território brasileiro, doenças cujas drogas desenvolvidas para seus respectivos tratamentos se deram, principalmente, entre as décadas de 40 e 50, não havendo desenvolvimento de relevantes inovações medicamentosas após este período. A leishmaniose é quantificada em 30 mil novos casos por ano. Já a tuberculose alcança o número de 70 mil novos casos por ano no Brasil (BRASIL. Ministério da Saúde. Portal do SUS). A favela da Rocinha, localizada na cidade do Rio de Janeiro, por exemplo, chegou a contabilizar 50 casos de tuberculose por mês no ano de 2008 (SOUZA, 2011, p. 313). Ainda no ano de 2011, entre o período de janeiro a outubro, a malária atingiu o registro de 217.298 novos casos na região Amazônica, local onde se concentra 99\% dos casos desta doença no Brasil (BRASIL. Ministério da Saúde. O SUS enfrenta malária).

De tal modo, somam-se a dependência das camadas mais pobres da população ao Serviço Único de Saúde ${ }^{17}$ de forma exclusiva, com as referidas "doenças da pobreza" e o fato de que tal população normalmente convive com a fome, com a vivência em moradias precárias, com a ausência de água limpa, com o desemprego ou com o trabalho em condições massacrantes, etc, o que acaba por contribuir para espalhar a falta de saúde e uma cultura mortífera e excludente (MARTIN In FERREIRA; OSELKA; GARRAFA, 1998, p. 175).

Assim, "a pobreza é um obstáculo para o acesso à saúde, o que demonstra que continua existindo uma correlação entre a classe social e a saúde" (RAMOS; RAMOS, 2016, p. 300), e, por consequência, a ocorrência da eutanásia social acaba por ter como vítimas principalmente a camada da população onde a pobreza e a extrema pobreza se fazem presentes, onde a dependência do atendimento pelo serviço público é a única esperança, vigorando, assim, como um instrumento que, além de matar, exclui socialmente tais populações, de forma cruel e dolorosa. Deste modo, o termo mistanásia acaba dando significado "à morte de milhares de pessoas sem nenhuma assistência, deixadas à própria sorte, em lixões, embaixo de viadutos, pontes, ruas e, principalmente, nos hospitais com corredores lotados, com pacientes moribundos e abandonados pelo Estado e por todos" (MENDONÇA; DA SILVA, 2014, p. 175), e cujo agente violador segue, infelizmente, sem responsabilização por tais mortes e pela exclusão institucionalizada que promove.

Deste modo, tem-se, por fim, a importância de se visualizar o direito à saúde como uma demanda ética por equidade e a necessidade de internalização de normas morais públicas para realizar progressivamente esse direito (RUGER, 2006, p. 326) ${ }^{18}$, bem como a ado-

17 No direito comparado, tem que "Mais de 42,5 milhões de americanos (15,5\%) não têm cobertura de seguro de saúde - um grande aumento desde os anos 90, apesar do forte desempenho da economia americana desde a recessão do início dos anos 90. Destes, 32,4\% dos pobres ou 10,4 milhões de pessoas estão sem cobertura." - tradução livre. KINNEY, 2000, p. 1475. No original: "Over 42.5 million Americans (15.5\%) have no health insurance coverage-a major increase since 1990s despite the strong performance of the American economy since the recession of the early 1990s. Of these, $32.4 \%$ of the poor or 10.4 million people are without coverage.".

18 No original: "[...] It emphasizes the importance of viewing the right to health as an ethical demand for equity in health and the need for the internalization of public moral norms to progressively realize this right.[...]". 
ção de uma perspectiva que compreenda que a efetivação do direito à saúde deve ser vista de forma prioritária, pois a ausência de um acesso igualitário acarreta, por vezes, em uma exclusão institucionalizada daqueles que dependem do acesso exclusivo da saúde pública, frequentemente precária e insuficiente.

\section{CONSIDERAÇÓES FINAIS}

Diante de todas as considerações tecidas no artigo, restou-se evidenciada a importância que o direito à saúde possui para a própria concretude do direito à vida e da dignidade da pessoa humana, figurando-se como um direito que além de ser humano e fundamental, pode ser considerado ainda como direito da personalidade, na medida em que ele mantém uma relação íntima com o núcleo dos referidos direitos, qual seja, a dignidade da pessoa humana, além do fato de que não há como se falar no pleno desenvolvimento da personalidade da pessoa se não é dado a cada indivíduo, de modo eficaz, a preservação e cuidado com a sua saúde e vida.

Ademais, por se tratar de um direito ímpar e que se inclui dentre os direitos caracterizados como "mínimo existencial" que deve ser garantido à cada pessoa, a arguição da reserva do possível pelo Estado, com o fim de justificar a sua omissão e ineficiência no que tange a promoção de políticas públicas de saúde à todos e a aplicação incorreta de recursos públicos, não deve ser levada como uma justificativa válida pelo ordenamento jurídico, por envolver um direito tão relevante, ou ao menos só deve ser considerado como argumento válido se efetivamente restar demonstrado que a limitação à sua efetivação se deu mediante a ponderação entre direitos conflitantes de mesma relevância e no qual se cumpriu os requisitos da proporcionalidade e com a preservação do conteúdo mínimo necessário para a garantia do exercício da vida com dignidade, sob pena de, aceitando indiscriminadamente tal alegação estatal, inviabilizar a própria materialidade do direito à saúde e continuar legitimando que consequências como a mistanásia se perpetuem.

Neste diapasão, se verificou ainda que a eutanásia social ou mistanásia em nada se assemelha com a eutanásia em si, pois ao passo que nela a morte também é antecipada, tal antecipação se dá de forma miserável, dolorida e cruel, fruto, na grande parte das vezes, da omissão estatal com relação a efetivação de um sistema de saúde que seja, de fato, acessível à todos e de qualidade, e não de um sistema inacessível por muitos, ou que quando acessado, é seletivo e precário, deixando perecer inúmeras pessoas sem um atendimento, no mínimo, adequado.

Assim, a eutanásia social se revela, não apenas um descaso com relação ao direito à saúde, mas também como uma atuação violadora perpetrada constantemente pelo Estado e cuja responsabilização e até mesmo o debate jurídico, por envolver justamente o grande "leviatã", ainda se faz invisível e, consequentemente, estimula a continuação dessa exclusão social institucionalizada, em especial da camada social abarcada pela pobreza e extrema pobreza, que dependem unicamente de um serviço público para que tenha a sua saúde tratada e preservada, bem como a sua dignidade respeitada. 
Desta forma, as respostas às problemáticas propostas no artigo vão no sentido de que a efetivação do direito à saúde é de suma importância na medida em que esse direito se revela como um direito humano, fundamental e da personalidade, necessário para a própria concretização da dignidade da pessoa humana e para um pleno e livre desenvolvimento da personalidade.

Ademais, fenômenos tão cruéis como a mistanásia permanecem praticamente invisíveis no cenário contemporâneo pois a mesma tem como agente causador justamente aquele que deveria proteger e efetivar os direitos à população, ou seja, o Estado, que não apenas promove (ou no mínimo, permite) que diversas mortes sejam perpetradas em razão de falhas e insuficiências na prestação de um serviço de saúde qualitativo e universal, mas também que, com isso, promove uma exclusão social institucionalizada das camadas pobres e extremamente pobres, isto porquê essa parcela da população tem unicamente o serviço público de saúde para recorrer e, além disso, normalmente possuem condições de vida precárias, sem moradias ou alimentação adequadas, com ausência de água limpa, etc., que facilitam a propagação da falta de saúde e a perpetuação de uma cultura mortífera e excludente das mesmas.

\section{REFERÊNCIAS}

BAHIA, Claudio José Amaral; ABUJAMRA, Ana Carolina Peduti. A justiciabilidade do direito fundamental à saúde: concretização do princípio constitucional da dignidade da pessoa humana. Revista Argumentum - UNIMAR, $\mathrm{n}$. 10, p. 295-318, 2009. Disponível em: http://ojs.unimar.br/index.php/revistaargumentum/article/view/1045/626. Acesso em: 24 nov. 2019.

BARROSO, Luis Roberto. A nova interpretação constitucional: ponderação, direitos fundamentais e relações privadas. Rio de Janeiro: Renovar, 2003.

BARROSO, Luís Roberto. Da falta de efetividade à judicialização excessiva: direito à saúde, fornecimento gratuito de medicamentos e parâmetros para a atuação Judicial. Jurisp. Mineira, Belo Horizonte, a. 60, n. 188, p. 29-60, jan./mar. 2009. Disponível em: https://bd.tjmg.jus.br/jspui/bitstream/tjmg/516/1/D3v1882009.pdf. Acesso em: 22 nov. 2019.

BARROSO, Luís Roberto. A dignidade da pessoa humana no direito constitucional contemporâneo: a construção de um conceito jurídico à luz da jurisprudência mundial. Trad. Humberto Laport de Mello. Belo Horizonte: Fórum, 2014.

BERNARDI, Renato; LAZARI, Rafael José Nadim de. Tem fundamento a crítica à incorporação da reserva do possível no sistema jurídico brasileiro?. In: SIQUEIRA, Dirceu Pereira; LEÃO JÚNIOR, Teófilo Marcelo de Arêa (Orgs). Direitos Sociais: uma abordagem quanto à (in)efetividade desses direitos - a Constituição de 1988 e suas previsões sociais. 1.ed. Birigüi, SP. Boreal Editora, 2011, p. 251-267.

BERTOLAIA, Denilson; PALAZZOLO, Massimo. A ordem social e a sua efetividade constitucional. Revista Direitos Humanos e Democracia, ano 4, n. 8, p. 271-309, jul./dez. 2016. Disponível em: https://www.revistas.unijui.edu.br/ index.php/direitoshumanosedemocracia/article/view/5899. Acesso em: 25 nov. 2019.

BRASIL. Constituição (1988). Constituição da República federativa do Brasil de 1988. Promulgada em 05 de outubro de 1988. Disponível em: http://www.planalto.gov.br/ccivil_03/constituicao/constituicao.htm. Acesso em: 22 nov. 2019.

CABETTE, Eduardo Luiz Santos. Eutanásia e Ortotanásia: comentários à Resolução 1.805/06 CFM. Aspectos Éticos e jurídicos. Curitiba: Juruá, 2009. 
CABRAL JÚNIOR, Luciano Roberto Gulart; COSTA, Eder Dion de Paula. Pobreza política e plano Brasil Sem Miséria. Revista Direitos Sociais e Políticas Públicas - UNIFAFIBE, v. 5, n. 2, p. 793-816, 2017. Disponível em: http://www. unifafibe.com.br/revista/index.php/direitos-sociais-politicas-pub/article/view/254/pdf_1. Acesso em: 24 nov. 2019.

CALDERÓN-VALENCIA, Felipe; ESCOBAR-SIERRA, Manuela. L'articulation de la juridiction spéciale pour la paix avec la justice ordinaire en matière d'extradition: les enjeux politiques du cas Jesus Santrich dans le contexte du post-conflit Colombien. Revista Direitos Sociais e Políticas Públicas - Unifafibe. V. 7, N. 1, 2019.

CANTALI, Fernanda Borghetti. Direitos da personalidade: disponibilidade relativa, autonomia privada e dignidade humana. Porto Alegre: Livraria do Advogado Editora, 2009.

CAPELO DE SOUZA, Rabindranath Valentino Aleixo. O direito geral da personalidade. Portugal: Coimbra Editora, 1995.

CIARLINI, Léa Martins Sales; CIARLINI, Alvaro Luis de Araujo. A estrutura das políticas públicas e os paradoxos da intervenção judicial por meio da ação civil pública: uma análise a partir dos cinco estágios do ciclo político-administrativo de Michael Howlett, Ramesh e Perl. Revista Direitos Sociais e Políticas Públicas - Unifafibe. V. 7, N. 1, 2019.

CUPIS, Adriano de. Os direitos da personalidade. Campinas- SP. Romana Jurídica, 2004.

DWORKIN, Ronald. Domínio da vida: aborto, eutanásia e liberdades individuais. Tradução de Jefferson Luiz Camargo; revisão da tradução de Silvana Vieira. São Paulo: Martins Fontes, 2003.

FERMENTÃO, Cleide Aparecida Gomes Rodrigues. Direito e axiologia - o valor da pessoa humana como fundamento para os direitos da personalidade. Revista Jurídica Cesumar-Mestrado, v. 7, n. 1, p. 57-80, 2007.

FERNANDES, David Augusto. Ânodo de sacrifício: a pobreza e a indignidade da pessoa humana. Revista Jurídica - UNICURITIBA, v. 3, n. 48, p. 299-319, 2017. Disponível em: http://revista.unicuritiba.edu.br/index.php/RevJur/ article/view/2182/1362. Acesso em: 24 nov. 2019.

FERREIRA, Clécia Lima; PORTO, Carolina Silva. Eutanásia no Direito Penal: os aspectos jurídicos do homicídio piedoso. Revista Direitos Humanos e Democracia, v. 5, n. 10, p. 150-174, 2017. Disponível em: https://www.revistas. unijui.edu.br/index.php/direitoshumanosedemocracia/article/view/6449. Acesso em: 25 nov. 2019.

FERREIRA, Olavo Augusto Vianna Alves; LEHFELD, Lucas de Souza; SIQUEIRA, Dirceu Pereira. A imunidade parlamentar segundo o supremo tribunal: análise do precedente sobre a prisão do senador Delcídio Amaral frente aos direitos da personalidade. Revista Direitos Sociais e Políticas Públicas - Unifafibe. V. 7, N. 2, 2019.

FOLLONE, Renata Ap; RODRIGUES, Rúbia Spirandelli. A perspectiva do direito de personalidade do idoso sob o fundamento da dignidade humana. In: SIQUEIRA, Dirceu Pereira; AMARAL, Sérgio Tibiriçá (Orgs.). Democracia, cidadania e os direitos da personalidade: uma releitura contemporânea. 1.ed. Birigui- SP. Boreal Editora, 2017, p. 314-330.

FLORIANI, Lara Bonemer Rocha; SANTOS, Luccas Farias. A hierarquia dos tratados internacionais e seus reflexos jurídicos e extrajurídicos. Revista Direitos Sociais e Políticas Públicas - Unifafibe. V. 7, N. 1, 2019.

GOMES, Fabiano Maranhão Rodrigues. Responsabilidade do Estado por ineficiência na prestação de serviços de saúde pública. Argumenta Jornal Law, n. 12, p. 163-190, 2010. Disponível em: http://seer.uenp.edu.br/index.php/ argumenta/article/view/165/165. Acesso em: 25 nov. 2019.

KANT, Immanuel. Fundamentação da Metafísica dos Costumes. In: Os pensadores - kant (II). Trad. Paulo Quintela. São Paulo: Abril Cultural, 1980.

KELBERT, Fabiana Okchstein. Reserva do possível e a efetividade dos direitos sociais no direito brasileiro. Porto Alegre: Livraria do Advogado, 2011.

KINNEY, Eleanor D. The international human right to health: What does this mean for our nation and world. Indiana Law Review, v. 34, p. 14571475, 2000. Disponível em: https://papers.ssrn.com/sol3/papers.cfm?abstract_ id=296394. Acesso em: 22 nov. 2019.

LASCANO, Alfonso Jaime Martinez. Inconvencionalidad del amparo mexicano por la eficacia en la protección judicial de derechos humanos. Revista Direitos Sociais e Políticas Públicas - Unifafibe. V. 7, N. 2, 2019. 
LOUREIRO, João Carlos. Responsabilidade (s), pobreza e mundo: para uma tópica (inter)constitucional da pobreza. In: CORREIA, Fernando Alves; MACHADO, Jónatas E. M; LOUREIRO, João Carlos. Estudos em homenagem ao Professor José Joaquim Gomes Canotilho. Coimbra: Editora Coimbra, 2012, p. 395 - 424.

MABTUM, Matheus Massaro; GERRA FILHO, Willis Santiago. A importância do tempo e sentido para a teoria dos sistemas de Niklas Luhmann. Revista Direitos Sociais e Políticas Públicas - Unifafibe. V. 6, N. 2, 2018.

MACIEL-LIMA, Sandra; OLIVEIRA, Francisco Cardozo; DOMINGOS, Isabela Moreira; Fundamental health rights: Microcefalia and sanitary policies to combat the Zika Virus. Revista Brasileira de Direito, v. 14, n. 3, p. 235-248, set./dez. 2018. Disponível em: https://seer.imed.edu.br/index.php/revistadedireito/article/view/2972/2028. Acesso em: 04/09/2019.

MARTIN, Leonard M. Eutanásia e Distanásia. In: FERREIRA, Sérgio Costa; OSELKA, Gabriel; GARRAFA, Volnei (org). Iniciação à Bioética. Brasília: Conselho Federal de Medicina, 1998. Disponível em:

https://portal.cfm.org.br/images/stories/biblioteca/iniciao\%20\%20biotica.pdf. Acesso em: 22 nov. 2019.

MASSAFRA, Cristiane Quadrado. Direito à saúde e desenvolvimento brasileiro: uma questão de cidadania. Revista Direito em Debate, v. 13, n. 22, p. 47-70, jul./dez. 2004. Disponível em: https://www.revistas.unijui.edu.br/index. php/revistadireitoemdebate/article/view/713. Acesso em: 25 nov. 2019.

MENDONÇA, Márcia Helena; DA SILVA, Marco Antonio Monteiro. Vida, dignidade e morte: cidadania e mistanásia. Ius Gentium, v. 9, n. 5, p. 151-190, 2014. Disponível em: https://www.uninter.com/iusgentium/index.php/iusgentium/article/view/150/124. Acesso em: 22 nov. 2019

MORAES, Carlos Alexandre. Responsabilidade civil dos pais na reprodução humana assistida. 1.ed. Rio de Janeiro: Forense; São Paulo: Método, 2019.

NEAL, Mary. Respect for human dignity as 'substantive basic norm'. International

Journal of Law in Context, v. 10, n. 1, p. 26-46, 2014. Disponível em: https://web.a.ebscohost.com/ehost/ pdfviewer/pdfviewer?vid=0\&sid=4194401a-9547-41e1-a62f-750df90b385f\%40sdc-v-sessmgr01. Acesso em: 25 nov. 2019.

Organização das Nações Unidas. Declaração Universal dos Direitos Humanos. 1948. Disponível em: https://www. ohchr.org/EN/UDHR/Documents/UDHR_Translations/por.pdf. Acesso em 22 nov. 2019.

Organização das Nações Unidas. Pacto Internacional sobre Direitos Econômicos, Sociais e Culturais. 1966. Disponível em: https://www.oas.org/dil/port/1966\%20Pacto\%20Internacional\%20sobre\%20os\%20Direitos\%20 Econ\%C3\%B3micos,\%20Sociais\%20e\%20Culturais.pdf. Acesso em: 22 nov. 2019.

Organização Mundial da Saúde. Constituição da Organização Mundial de Saúde.1946. Disponível em: http:// www.direitoshumanos.usp.br/index.php/OMS-Organiza\%C3\%A7\%C3\%A3o-Mundial-da-Sa\%C3\%BAde/constituicao-da-organizacao-mundial-da-saude-omswho.html. Acesso em: 22 nov. 2019.

OTERO, Cleber Sanfelici; HILLE, Marcelo Luiz. A dignidade da pessoa humana em face da escassez de recursos do Estado. Revista Jurídica Cesumar, v. 13, n. 2, p. 485-511, jul./dez. 2013. Disponível em: http://periodicos.unicesumar.edu.br/index.php/revjuridica/article/view/3098/2136. Acesso em: 06 nov. 2019.

OTERO, Cleber Sanfelici; MASSARUTTI, Eduardo Augusto de Souza. Em conformidade com o direito fundamental à saúde previsto na Constituição brasileira de 1988, é possível exigir do Estado a prestação de fosfoetanolamina sintética para pessoas com câncer?. Revista Jurídica Cesumar, v. 16, n. 3, p. 847-876, set./ dez. 2016, p. 856. Disponível em: http://periodicos.unicesumar.edu.br/index.php/revjuridica/article/view/5380/2890. Acesso em: 06 nov. 2019.

PAOLO, Edvige Di; RIBAS, Luciane Aparecida; PEREIRA, Maria Regina Rodrigues. Eutanásia Social: Um Estudo de Caso da População de Rua de Juiz de Fora. CES Revista. Juiz de Fora, 2006.

PAUGAM, Serge. O conceito de desqualificação social. In: VÉRAS, Maura Pardini Bicudo (Org.). Por uma sociologia da exclusão social: o debate com Serge Paugam. São Paulo: EDUC, 1999.

PEREZ LUÑO, Antonio Henrique. Derechos Humanos, Estado de Derecho y Constitución. 
PICCIRILLO, Miguel Belinati; ZAIA, Raíssa Dias. A inefetividade do direito à saúde no Brasil. Revista Direitos Sociais e Políticas Públicas - UNIFAFIBE, v. 4, n. 2, p. 319-355, 2016. Disponível em: http://www.unifafibe.com.br/revista/ index.php/direitos-sociais-politicas-pub/article/view/173/pdf_1. Acesso em: 04/09/2019.

RAMOS, Paulo Roberto Barbosa; RAMOS, Edith Maria Barbosa. Direito à saúde, necessidades básicas e dignidade da pessoa humana. Revista Jurídica, v.3, n. 44, p. 275-304, 2016. Disponível em: http://revista.unicuritiba.edu.br/ index.php/RevJur/article/view/1747/1141. Acesso em: 22 nov. /2019.

RAMOS, Edith Maria Barbosa; DINIZ, Isadora Moraes. O direito à saúde e a ideia de proteção social na Constituição Federal de 1988: notas iniciais. Revista Direito em Debate, v.26, n. 48, p. 159-184, jul./dez. 2017. Disponível em: https://www.revistas.unijui.edu.br/index.php/revistadireitoemdebate/article/view/5906. Acesso em: 25 nov. 2019.

RIBEIRO, Maria de Fátima. Efetivação de políticas públicas: uma questão orçamentária. Revista Argumentum - UNIMAR, v. 12, p. 77-102, 2011. Disponível em: http://ojs.unimar.br/index.php/revistaargumentum/article/ view/1068/662. Acesso em: 04/09/2019.

ROSSIGNOLI, Marisa; SOUZA, Francielle Calegari de. O princípio constitucional da livre concorrência frente a política do desenvolvimento sustentável. Revista Direitos Sociais e Políticas Públicas - Unifafibe. V. 7, N. 1, 2019.

RUGER, Jennifer Prah. Toward a theory of a right to health: capability and incompletely theorized agreements. Yale Journal of Law \& the Humanities, v. 18, n. 2, p. 273-326, 2006. Disponível em: https://papers.ssrn.com/sol3/ papers.cfm?abstract_id=933009. Acesso em: 22 nov. 2019.

SÁ, Maria de Fátima Freire de; NAVES, Bruno Torquato de Oliveira. Manual de Biodireito. Belo Horizonte: Del Rey, 2011.

SARLET, Ingo Wolfgang; FIGUEIREDO, Mariana Filchtiner. Reserva do possível, mínimo existencial e direito à saúde. Revista Brasileira de Direitos Fundamentais \& Justiça, v. 1, n. 1, p. 171-213, 2007. Disponível em: http://dfj. emnuvens.com.br/dfj/article/view/590/73. Acesso em: 25 nov. 2019.

SARLET, Ingo Wolfgang. Dignidade da pessoa humana e direitos fundamentais na Constituição de 1988. 7.ed. rev. atu. Porto Alegre: Livraria do Advogado, 2009-a.

SARLET, Ingo Wolfgang. As dimensões da dignidade da pessoa humana: construindo a compreensão jurídico constitucional necessária e possível. In: SARLET, Ingo Wolfgang (Org.). Dimensões da dignidade: ensaios de filosofia do direito e do direito constitucional. 2.ed. Porto Alegre: Livraria do Advogado, 2009-b.

SARMENTO, Daniel. Direitos fundamentais e relações privadas. Rio de Janeiro: Editora Lumen Juris, 2004.

SELAYARAN, Alexandre; MACHADO, Guilherme; MORAIS, Fausto. A (não) conexão entre judicialização excessiva do direito à saúde e ativismo judicial. Revista Direitos Sociais e Políticas Públicas - UNIFAFIBE, v. 6, n. 2, p. 1-27, 2018. Disponível em: http://www.unifafibe.com.br/revista/index.php/direitos-sociais-politicas-pub/article/ view/315/pdf. Acesso em: 25 nov. 2019.

SEN, Amartya. Desenvolvimento como liberdade. Tradução: Laura Teixeira Motta. São Paulo: Companhia das Letras, 2010.

SHAFIQUE, Sohana; BHATTACHARYYA, Dipika S., ANWAR, Iqbal; ADAMS, Alayne. Right to health and social justice in Bangladesh: ethical dilemmas and obligations of state and non-state actors to ensure health for urban poor. BMC medical ethics, v. 19, n. 1, p. 61-69, 2018. Disponível em: https://web.a.ebscohost.com/ehost/pdfviewer/ pdfviewer?vid=0\&sid=8c865c5e-d536-429f-919f-c074364a3fe4\%40sessionmgr4007. Acesso em: 24 nov. 2019.

SILVA, Diogo Bacha e; GONÇALVES, Luciano Meni. Judicialização da saúde e a transferência do controle sobre o corpo. Revista Jurídica Cesumar, v. 13, n. 2, p. 561-579, jul./dez. 2013. Disponível em: http://periodicos.unicesumar.edu.br/index.php/revjuridica/article/view/3047/2139. Acesso em: 06 nov. 2019.

SILVA, Karina Zanin da; VITA, Jonathan Barros. O princípio da reserva do possível e o direito fundamental à saúde. Revista Jurídica Cesumar, v. 14, n. 1, p. 241-264, jan./jun. 2014. Disponível em: http://periodicos.unicesumar.edu. br/index.php/revjuridica/article/view/3439/2298. Acesso em: 06 nov. 2019. 
SIQUEIRA, Dirceu Pereira; LAZARETTI, Bruna Furini. Eutanásia social e os direitos da personalidade: uma leitura constitucional crítica. Argumenta Jornal Law, n. 30, p. 297-329, jan./ junho 2019. Disponível em: http://seer.uenp. edu.br/index.php/argumenta/article/view/1571/pdf. Acesso em:21 nov. 2019.

SOARES, Marcelo Negri; KAUFFMAN, Marcos Eduardo; MARTIN, Raphael Farias. Economy law and economic analysis of law and the impacto on intellectual property in the common law system. Revista Direitos Sociais e Políticas Públicas - Unifafibe. V. 7, N. 2, 2019.

SOUZA, Jessé. A ralé brasileira: quem é e como vive. Belo Horizonte: Ed. UFMG. 2011.

STURZA, Janaína Machado; RODRIGUES, Bruna dos Passos. Diálogos entre políticas públicas e direito à saúde: as audiências públicas enquanto instrumento de participação popular sob a perspectiva da teoria da ação comunicativa de Habermas. Revista Direitos Sociais e Políticas Públicas - Unifafibe. V. 7, N. 2, 2019.

SZANIAWSKI, Elimar. Direitos da personalidade e sua tutela. 2.ed. rev. atual. e ampl. São Paulo: Editora Revista dos Tribunais, 2005.

TASCA, Jocimar Antonio. A judicialização da saúde. Revista Direitos Sociais e Políticas Públicas - UNIFAFIBE, v. 1, n. 1, p. 93-118, 2013. Disponível em: http://www.unifafibe.com.br/revista/index.php/direitos-sociais-politicas-pub/article/view/7/pdf_4. Acesso em: 04/09/2019.

TEIXEIRA, Sílvia Gabriel. Combate a pobreza: a responsabilidade de proteger da comunidade internacional. Revista Direitos Sociais e Políticas Públicas - UNIFAFIBE, v. 3, n. 1, p. 195-240, 2014. Disponível em: http://www.unifafibe. com.br/revista/index.php/direitos-sociais-politicas-pub/article/view/59/pdf_39. Acesso em: 25 nov. 2019.

VIDAL DE SOUZA, José Fernando; SANOMIYA, Bárbara Ryukiti. Mínimo existencial ecológico e a judicialização das políticas públicas. Revista Brasileira de Direito, v. 13, n. 3, p. 381-407, dez. 2017 Disponível em: https://seer.imed. edu.br/index.php/revistadedireito/article/view/1742. Acesso em: 25 nov. 2019.

WEDY, Gabriel. Desenvolvimento sustentável como direito fundamental e o princípio da dignidade da pessoa humana. Revista Brasileira de Direitos Fundamentais \& Justiça, v. 12, n. 38, jan./jun. 2018. Disponível em: http:// dfj.emnuvens.com.br/dfj/article/view/723/939. Acesso em: 25 nov. 2019.

ZAGANELLI, Margareth Vetis; SOUZA, Carlos Henrique Medeiros de; CABRAL, Hildeliza Lacerda Tinoco Boechat; SANCHES, Letícia Carvalho. Eutanásia social: "morte miserável" e a judicialização da saúde. Lima, Peru: Derecho y Cambio Social, n. 43 - ano XIII - 2016. Disponível em: https://www.derechoycambiosocial.com/revista043/ EUTANASIA_SOCIAL.pdf. Acesso em: 22 nov. 2019.

ZEIFERT, Anna Paula Bagetti. Pensar as políticas públicas a partir do enfoque das capacidades: justiça social e respeito aos direitos humanos. Revista Direitos Sociais e Políticas Públicas - Unifafibe. V. 7, N. 1, 2019.

Recebido/Received: 08.05.2020.

Aprovado/Approved: 30.05.2020. 